\title{
Commentary \\ Arginine vasopressin in septic shock: supplement or substitute for norepinephrine?
}

\author{
Sebastian Rehberg ${ }^{1,2}$, Perenlei Enkhbaatar ${ }^{1}$ and Daniel L Traber $^{1}$
}

${ }^{1}$ Investigational Intensive Care Unit, Department of Anesthesiology, The University of Texas Medical Branch, 301 University Blvd, Galveston, TX 77555, USA

2Department of Anesthesiology and Intensive Care, University of Muenster, Albert-Schweitzer-Str. 33, 48149 Muenster, Germany

Corresponding author: Sebastian Rehberg, serehber@utmb.edu

Published: 14 August 2009

This article is online at http://ccforum.com/content/13/4/178

(c) 2009 BioMed Central Ltd

See related research by Simon et al., http://ccforum.com/content/13/4/R113
Critical Care 2009, 13:178 (doi:10.1186/cc7985)

\begin{abstract}
In the current issue of Critical Care, Simon and coworkers investigated the effects of first-line arginine vasopressin (AVP) on organ function and systemic metabolism compared with norepinephrine in a pig model of fecal peritonitis. AVP was titrated according to the mean arterial pressure suggesting a vasopressor rather than a hormone replacement therapy. The study provides some evidence for the safety of this therapeutic approach. It needs to be determined whether AVP is most beneficial as a constant low-dose infusion to supplement norepinephrine or in higher doses than currently recommended to substitute norepinephrine. In addition, future studies are warranted to evaluate whether a firstline therapy of AVP is superior to a last-resort administration.
\end{abstract}

In the current issue of Critical Care, Simon and coworkers carefully investigated the effects of arginine vasopressin (AVP) on myocardial, hepatic and renal function as well as on systemic metabolism compared with norepinephrine in a pig model of fecal peritonitis [1]. Both compounds were titrated to keep the mean arterial pressure (MAP) at baseline values. Maximum doses were limited to $5 \mathrm{ng} / \mathrm{kg} / \mathrm{min}$ for AVP (equivalent to $0.14 \mathrm{IU} / \mathrm{min}$ in a $70 \mathrm{~kg}$ patient) and to norepinephrine doses causing a heart rate $\geq 160$ beats $/ \mathrm{min}$. AVP reduced systolic myocardial contractility, cardiac output, heart rate and troponin I levels compared with norepinephrine. In addition, kidney and liver injury were attenuated and the rate of direct aerobic glucose oxidation was increased in AVPtreated animals. The authors concluded that, with respect to myocardial, renal and liver function, AVP seems to represent a safe therapeutic approach in well-resuscitated septic shock.

Although exclusively focused on by the authors, this elaborate study does not solely extend our knowledge from previous experimental studies [2,3] and clinical trials [4,5] about the safety of AVP in septic shock. The study protocol rather reveals some interesting differences compared with recent experiments. Based on the relative AVP deficiency in septic shock [6], AVP is prevailingly administered as a continuous low-dose infusion (0.02 to $0.04 \mathrm{lU} / \mathrm{min})$. This so-called hormone replacement therapy [7] usually leads to AVP plasma levels of about $100 \mathrm{pmol} / \mathrm{ml}[6,8]$. In contrast, the titration of AVP according to MAP in the present study implies the primary intention of AVP as a vasopressor [9,10]. Accordingly, higher AVP doses are necessary to achieve the individual threshold values. In this context, a retrospective, controlled study in 78 patients with vasodilatory shock reported that higher doses of AVP (0.067 vs. $0.033 \mathrm{IU} / \mathrm{min}$ ) were more efficient than and as safe as the low-dose regimen [11].

The maximum dose of AVP administered in the present study was almost five times higher than in the Vasopressin And Septic Shock Trial (0.14 vs. $0.03 \mathrm{IU} / \mathrm{min}$ ) [8]. Whether this dose corresponds to the calculated dose in humans, however, remains unclear. Since lysine vasopressin and not AVP represents the endogenous hormone in pigs, vasopressin receptors might be less sensitive to exogenously administered AVP than in humans. Besides the receptor sensitivity, the AVP plasma levels would have been of interest, because a differentiation between endogenous and exogenous vasopressin might have been possible.

AVP was used as a sole first-line therapy representing a substitute for, and not a supplement to, the standard treatment with norepinephrine. Notably, in contrast to a recent experimental study in ovine septic shock [2], AVP was not only able to restore but also to maintain the MAP at baseline values with minimal supplementation of norepinephrine at the end of the 24 -hour observation period $(0.06 \mu \mathrm{g} / \mathrm{kg} / \mathrm{min})$. This

$\mathrm{AVP}=$ arginine vasopressin $\mathrm{MAP}=$ mean arterial pressure. 
finding may be explained by the less severe septic shock at the time of treatment initiation (drop in MAP of 10\% in the present study vs. $30 \%$ in the latter study) and is in line with the results of a subgroup analysis from the Vasopressin And Septic Shock Trial [8].

Unfortunately, the design of the present study does not allow a fair comparison between both treatment strategies, because AVP was supplemented with norepinephrine after the maximum dose was reached, while there was no AVP supplementation in the norepinephrine group. In a randomized, controlled, open-label trial in 23 patients with septic shock, however, the first-line therapy of 0.04 to $0.20 \mathrm{U} / \mathrm{min}$ AVP reduced norepinephrine requirements and improved renal function and Sequential Organ Failure Assessment scores compared with norepinephrine. Notably, only $36 \%$ of the patients treated with AVP were supplemented with norepinephrine [12].

Reviewing the current literature on this topic together with the work of Simon and coworkers, the proposed treatment strategy for AVP in septic shock (constant low-dose infusion as a supplement to norepinephrine in catecholamine-resistant shock) might not represent the optimal approach. A first-line therapy, even in doses higher than currently recommended by the guidelines of the Surviving Sepsis Campaign [13], might be superior to a last-resort administration. At least, the present study provides some evidence for the safety of this therapeutic approach. In addition, a titration of AVP doses according to the MAP might be more effective than a hormone replacement therapy. Future studies are now needed to further investigate the most beneficial dose regimen and time of treatment initiation for AVP in septic shock.

\section{Competing interests}

The authors declare that they have no competing interests.

\section{References}

1. Simon F, Giudici R, Scheuerle A, Groger M, Asfar P, Vogt JA, Wachter U, Ploner F, Georgieff M, Moller P, Laporte R, Radermacher P, Calzia E, Hauser B: Comparison of cardiac, hepatic, and renal effects of arginine vasopressin and noradrenaline during porcine fecal peritonitis: a randomized controlled trial. Crit Care 2009, 13:R113.

2. Rehberg S, Ertmer C, Kohler G, Spiegel HU, Morelli A, Lange M, Moll K, Schlack K, Van Aken H, Su F, Vincent JL, Westphal M: Role of arginine vasopressin and terlipressin as first-line vasopressor agents in fulminant ovine septic shock. Intensive Care Med 2009, 35:1286-1296.

3. Sun Q, Dimopoulos G, Nguyen DN, Tu Z, Nagy N, Hoang AD, Rogiers $P$, De Backer D, Vincent JL: Low-dose vasopressin in the treatment of septic shock in sheep. Am J Respir Crit Care Med 2003, 168:481-486.

4. Dunser MW, Mayr AJ, Ulmer H, Knotzer H, Sumann G, Pajk W, Friesenecker $B$, Hasibeder WR: Arginine vasopressin in advanced vasodilatory shock: a prospective, randomized, controlled study. Circulation 2003, 107:2313-2319.

5. Luckner G, Dunser MW, Jochberger S, Mayr VD, Wenzel V, Ulmer H, Schmid S, Knotzer H, Pajk W, Hasibeder W, Mayr AJ, Friesenecker B: Arginine vasopressin in $\mathbf{3 1 6}$ patients with advanced vasodilatory shock. Crit Care Med 2005, 33:2659-2666.

6. Landry DW, Levin HR, Gallant EM, Ashton RC Jr, Seo S, D'Alessandro $\mathrm{D}, \mathrm{Oz} \mathrm{MC}$, Oliver JA: Vasopressin deficiency contributes to the vasodilation of septic shock. Circulation 1997, 95:1122-1125.

7. Vincent JL: Endocrine support in the critically ill. Crit Care Med 2002, 30:702-703.

8. Russell J, Walley K, Singer J, Gordon A, Hébert P, Cooper D, Holmes C, Mehta S, Granton J, Storms M, Cook DJ, Presneill JJ, Ayers D: Vasopressin versus norepinephrine infusion in patients with septic shock. N Engl J Med 2008, 358:877-887.

9. Klinzing S, Simon M, Reinhart K, Bredle DL, Meier-Hellmann A: High-dose vasopressin is not superior to norepinephrine in septic shock. Crit Care Med 2003, 31:2646-2650.

10. Westphal M, Freise $H$, Kehrel BE, Bone HG, Van Aken H, Sielenkamper AW: Arginine vasopressin compromises gut mucosal microcirculation in septic rats. Crit Care Med 2004, 32:194-200

11. Luckner G, Mayr VD, Jochberger $S$, Wenzel V, Ulmer $H$, Hasibeder WR, Dünser MW: Comparison of two dose regimens of arginine vasopressin in advanced vasidilatory shock. Crit Care Med 2007, 35:2280-2285.

12. Lauzier F, Levy B, Lamarre $P$, Lesur O: Vasopressin or norepinephrine in early hyperdynamic septic shock: a randomized clinical trial. Intensive Care Med 2006, 32:1782-1789.

13. Dellinger RP, Levy MM, Carlet JM, Bion J, Parker MM, Jaeschke R, Reinhart K, Angus DC, Brun-Buisson C, Beale R, Calandra T, Dhainaut JF, Gerlach H, Harvey M, Marini JJ, Marshall J, Ranieri M, Ramsay G, Sevransky J, Thompson BT, Townsend S, Vender JS, Zimmerman JL, Vincent JL: Surviving Sepsis Campaign: international guidelines for management of severe sepsis and septic shock: 2008. Crit Care Med 2008, 36:296-327. 